\title{
Rapid maxillary expansion as a treatment for obstructive sleep apnea syndrome in children and adolescents: an evaluation by polysomnography and quality of life
}

\author{
Expansão rápida da maxila como tratamento da síndrome da apneia obstrutiva do sono na criança \\ e no adolescente: avaliação por polissonografia e qualidade de vida
}

Expansión rápida maxilar como tratamiento del síndrome de apnea obstructiva del sueño en niños y adolescentes: evaluación por polisomnografía y calidad de vida

\author{
Letícia Cabrera Capalbo \\ ORCID: https://orcid.org/0000-0003-2775-9263 \\ São Paulo State University, Brazil \\ E-mail: lecapalbo@gmail.com \\ Renan Dal-Fabbro \\ ORCID: https://orcid.org/0000-0002-4125-8441 \\ São Paulo State University, Brazil \\ E-mail: renandalfabro@gmail.com \\ Ana Laura Modesto de Albuquerque Donine \\ ORCID: https://orcid.org/0000-0002-9796-7888 \\ São Paulo State University, Brazil \\ E-mail: ana.albuquerque@unesp.br \\ Juliana Sobreira Saraiva \\ ORCID: https://orcid.org/0000-0002-2099-1564 \\ São Paulo State University, Brazil \\ E-mail: julianassaraiva@gmail.com \\ Renato Bigliazzi \\ ORCID: https://orcid.org/0000-0002-8163-179X \\ São Paulo State University, Brazil \\ E-mail: bigliazzir@hotmail.com \\ Silke Anna Theresa Weber \\ ORCID: https://orcid.org/0000-0003-3194-3039 \\ São Paulo State University, Brazil \\ E-mail: silke@fmb.unesp.br \\ André Pinheiro de Magalhães Bertoz \\ ORCID: https://orcid.org/0000-0002-1746-3138 \\ São Paulo State University, Brazil \\ E-mail: drbertoz@hotmail.com
}

\begin{abstract}
Sleep-related breathing disorders range from snoring to more serious disorders, such as Obstructive Sleep Apnea Syndrome (OSAS). It affects the quality of life of children and are related to mouth breathing, one of the main causes of malocclusion. The aim of this research was to evaluate the polysomnography respiratory data and quality of life in patients diagnosticated with OSAS before and after rapid maxillary expansion (RME). Children aged 7 to 11 were included, all of them presented respiratory complaints of snoring with or without associated respiratory pauses. Children with genetic and craniofacial syndromes, neuropaths, children with grade 4 tonsils or signs of OSAS severity with cyanosis, pulmonary hypertension or pulmonale were excluded. All children underwent occlusal examination and type 3-night polysomnography, in addition to filling out the OSA 18 quality of life questionnaires and the Sleep Disorders Scale in Children. The data were compared before (T0) and after (T1) RME procedure. For parametric values, paired t test was used, and for the non-parametric ones, the Wilcoxon test was applied. There was a significant variation in $\mathrm{AHI}$ from $\mathrm{T} 0=6.89$ to $\mathrm{T} 1=5.34$, as well as a significant reduction in OSA 18 scores in $46.2 \%$ of cases. RME was effective for the treatment of OSAS considering polysomnography results and also improved quality of life in children.
\end{abstract}

Keywords: Sleep apnea obstructive; Quality of life; Polysomnography; Palatal expansion technique.

\section{Resumo}

Os distúrbios respiratórios relacionados ao sono variam do ronco a distúrbios mais graves, como a síndrome da apnéia obstrutiva do sono (SAOS). Afeta a qualidade de vida das crianças e está relacionada à respiração bucal, uma das principais causas das maloclusões. O objetivo desta pesquisa foi avaliar os dados polissonográficos respiratórios e a qualidade de vida em pacientes com diagnóstico de SAOS antes e após a expansão rápida da maxila (ERM). Foram 
incluídas crianças de 7 a 11 anos, todas com queixas respiratórias de roncos com ou sem pausas respiratórias associadas. Foram excluídas crianças com síndromes genéticas e craniofaciais, neuropatas, crianças com tonsilas grau 4 ou sinais de gravidade da SAOS com cianose, hipertensão pulmonar ou pulmonale. Todas as crianças foram submetidas a exame oclusal e polissonografia do tipo 3 noites, além do preenchimento dos questionários de qualidade de vida OSA 18 e da Escala de Distúrbios do Sono em Crianças. Os dados foram comparados antes (T0) e depois (T1) do procedimento ERM. Para os valores paramétricos foi utilizado o teste t pareado e, para os não paramétricos, o teste de Wilcoxon. Houve variação significativa no IAH de T0 =6,89 a T1 = 5,34, bem como redução significativa nos escores de OSA 18 em 46,2\% dos casos. A ERM foi eficaz no tratamento da SAOS considerando os resultados da polissonografia e também melhorou a qualidade de vida das crianças.

Palavras-chave: Apneia obstrutiva do sono; Qualidade de vida; Polissonografia; Técnica de expansão palatina.

\section{Resumen}

Los trastornos respiratorios relacionados con el sueño van desde ronquidos hasta trastornos más graves como el síndrome de Apnea Obstructiva del Sueño (AOS). Afecta la calidad de vida de los niños y está relacionado con la respiración bucal que es una de las principales causas de maloclusiones. El objetivo de esta investigación fue evaluar los datos polisomnograficos respiratorios y la calidad de vida en pacientes diagnosticados con AOS antes y después de la expansión rápida del maxilar (ERM). Se incluyeron niños de 7 a 11 años con molestias respiratorias de ronquido con o sin pausas respiratorias asociadas. Se excluyeron los niños con síndromes genéticos y craneofaciales, neuropatías, niños con amígdalas grado 4 o signos de gravedad de AOS con cianosis, hipertensión pulmonar o cor pulmonale. A todos los niños se les realizó examen oclusal y polisomnografía de 3 noches, además de completar los cuestionarios de calidad de vida OSA 18 y la Escala de Trastornos del Sueño en Niños. Los datos se compararon antes (T0) y después (T1) del procedimiento ERM. Para los valores paramétricos se utilizó la prueba t pareada y, para los no paramétricos, la prueba de Wilcoxon. Se encontró una variación significativa en el IAH de T0 = 6,89 a T1 = 5,34, así como una reducción significativa en las puntuaciones de AOS 18 en el 46,2\% de los casos. ERM fue eficaz en el tratamiento del AOS considerando los resultados de la polisomnografía y también mejoró la calidad de vida de los niños.

Palabras clave: Apnea obstructiva del sueño; Calidad de vida; Polisomnografía; Técnica de expansión palatina.

\section{Introduction}

Obstructive Sleep Apnea Syndrome (OSAS) has aroused interest because it is a condition that has not been fully established in medicine. It is a pathological condition that includes damage of multidimensional characteristics and harms the patient in physical-functional and psychosocial dimensions. It comes from a recurrent obstruction in the upper airway during sleep, and intermittent hypoxemia, causing awakenings that can result in harmful health effects, including neurocognitive problems and cardiovascular morbidity (Chaves Junior CM, 2017).

There is an explicit need to detect sleep problems in the pediatric population to verify the initial processes of cognitive, behavioral, health and quality of life, as OSAS can cause several changes in craniofacial development, including thoracic deformities, cognitive-behavioral and cardiovascular changes and repercussions on stature development and growth (Luzzi et al., 2016).

Children with OSAS often have characteristics of adenotonsillar hypertrophy, small and narrow nasal cavity and atresia of the maxilla, associated with the high palate and posterior crossbite. Given the high prevalence of patients with OSAS, portable monitoring of type 3 polysomnography was validated to facilitate access to diagnosis. The use of the portable monitoring device (Stardust II - STD) proved to be useful as a tool to verify or exclude the diagnosis of OSAS, and should record air flow, respiratory effort, heart rate and blood oxygenation.

The OSAS is classified according to the apnea and hypopnea index (AHI) obtained in the polysomnography exam, based on the frequency of respiratory events during sleep, being mild (AHI between 5 and 15 events / hour), moderate (AHI between 15 and 30 events / hour) or severe (AHI> 30 events / hour), allowing the dimension of the severity of symptoms and complications that may occur in the long term to be dimensioned, in addition to enabling treatment targeting (Campostrini DDA, 2014).

Insufficient sleep duration, as well as disturbed sleep, are associated with low school performance, difficulty in concentration / focus, daytime sleepiness and school absence, and predict the occurrence of problems in interpersonal and 
psychosocial functioning. The assessment of the concept of quality of life has been recognized as an important health measure in dentistry since an unpleasant dental appearance can stigmatize a person, hinder professional achievement, encourage negative stereotypes and harm self-esteem (Di Francesco, Fortes, \& Komatsu, 2004; Tan, Alonso Alvarez, Tsaoussoglou, Weber, \& Kaditis, 2017).

The use of intraoral devices is an effective alternative in the treatment of sleep apnea in children of an established age group. Rapid maxillary expansion (RME) specifically is a simple and effective procedure as it promotes palatal disjunction through a fixed expander, such as the Hyrax type (Ruiz, Cruz, Ferreira, Aguiar, \& Silva, 2018). This device is located parallel to the medial palatine suture, activated to accumulate a significant amount of strength to the point of breaking the resistance offered by the suture (Kaditis et al., 2016).

In this context, this study aimed to evaluate the respiratory data of the polysomnographic examination and the quality of life in patients with sleep-disordered breathing before and after rapid maxillary expansion.

\section{Methodology}

This prospective cohort study was carried out in 26 children aged between 7 and 11 years old, selected in municipal schools in Araçatuba - SP - Brazil. The study was approved by the Human Research Ethics Committee of Universidade Estadual Paulista Júlio de Mesquita Filho, SP, Brazil (CAAE 89821218.1.0000.5420). All participants and their guardians were informed about the exam procedures and authorized their participation in writing through the Free and Informed Consent Term (IC), with knowledge of the nature and format of the study, in compliance with the regulated health research rules by CNS resolution 466/12 (Brasil, 2012).

Inclusion criteria were age range, malocclusion (molar relationship, deep bite and crossbite) and signs and symptoms of sleep-disordered breathing such as snoring, mouth breathing and observed breathing pauses. Patients with a previous history of orthodontic treatment, presence of dimorphism and / or craniofacial anomalies or patients with desaturation below 80\% were excluded from the study.

The selected individuals were submitted to three quantitative methods (Pereira et al, 2018, consisted by a type 3 allnight polysomnography, and answered the OSA-18 quality of life questionnaires and the Sleep Disorders Scale in Children, translated and validated for the Brazilian population (Ferreira et al., 2009). Type 3 polysomnography assesses the following points: Airflow through the nasal pressure cannula that also makes it possible to detect snoring, an electric piezo strap for detecting respiratory effort, pulse oximetry and pulse rate. Participants were instructed in the installation and handling of the device according to the manufacturer's recommendation. The installation and measurement of results were analyzed by a single qualified operator and approved by a sleep specialist, according to AAMS regulations (Kapur et al., 2017).

The OSA-18 questionnaire presents 18 items grouped into 5 domains, whose items are scored on an ordinal scale of 7 points ( 1 - no time, 2 - almost no time, 3 - few times, 4 - sometimes, 5 - several times, 6 - most of the time, 7 - every time). Thus, the OSA-18 domains can obtain the following scores: a) sleep disorder (4 items with scores ranging from 4 to 28 ); b) physical suffering (4 items with scores ranging from 4 to 28); c) emotional distress (3 items with scores ranging from 3 to 21 ); d) daytime problems (3 items with scores ranging from 3 to 21); e) concerns of parents or guardians (4 items with scores ranging from 4 to 28) (F. M. V. S. Fernandes \& Teles, 2013).

The final score of OSA-18 is obtained by the simple sum of the items, and can vary from 18 to 126 , being categorized in three levels, according to the impact on the children's quality of life: mild (scores less than 60), moderate (scores between 60 and 80) and severe (scores above 80) (Franco, Rosenfeld, \& Rao, 2000). The Sleep Disturbance Scale in Children is an instrument with 26 items for the assessment in children aged 3 to 18 years, capable of differentiating the following disorders: sleep onset and maintenance disorders, sleep breathing disorders, sleep disorders awakening, sleep-wake transition disorders, 
excessive daytime sleepiness and sleep hyperhidrosis (Bruni et al., 1996).

All patients underwent treatment with a Hyrax device for rapid maxillary expansion, an orthodontic-orthopedic procedure that uses fixed appliances anchored in posterior teeth and welded to an expander screw, located in the palate region. A force is applied on the anchor teeth, to act on the palatal suture, without any tooth movement (L. C. Fernandes, Farinazzo Vitral, Noritomi, Schmitberger, \& José da Silva Campos, 2019). Orthopedic movement occurs by opening the still uncalcified palatal suture, up to approximately 12 years of age, or newly calcified, in adolescence. The total effect of the expansion consists of a movement of the maxillary complex, increasing the nasal cavity with improved airflow (Huynh, Desplats, \& Almeida, 2016; Pirelli, Saponara, \& Guilleminault, 2004; Rana et al., 2020).

The activation protocol of the appliance used was: after installation, the patient remained with the device for one month without activation, to get used to it; after that time, activation was made in the office with 4/4 laps (one full lap), instructing the person in charge to activate a quarter lap in the morning and a quarter lap at night every day until the complete correction of the transversal problem, and during this period of activation, the patient had weekly follow-up at the dental office (Maspero et al., 2020; Weissheimer et al., 2011). At the end of the disjunction, the patients stayed another 6 months with the device in position for containment, allowing the formation of bone in the palatal suture (Costa, Galindo, Mattos, \& CurySaramago, 2017). The suture opening and consequent efficacy of the RME treatment was observed by clinical and (interincisal diastema) radiographic signs.

At the end of the procedure, all patients underwent a new polysomnographic assessment, and the OSA-18 questionnaires and the Sleep Disorders Scale in Children were again applied to compare the results and verify the improvement in breathing and quality of life of these patients. The data were submitted to statistical analysis using the GraphPad Prism 7.0 program (GraphPad Software Inc). For the parametric values, the paired t test was used, and for the non-parametric ones, the Wilcoxon test, both with a $5 \%$ significance level.

\section{Results and Discussion}

The distribution of 26 children, according to sex and age, is shown in Table 1. We can see that there was a greater participation of females, and the average duration of treatment for all participants was around four months.

Table 1 - Characteristics of the participants.

\begin{tabular}{l|l}
\hline \hline & Total \\
\hline \hline Female (n, \%) & $16(61.54 \%)$ \\
\hline Male (n, \%) & $10(38.46 \%)$ \\
\hline Age at T0 & $8.6 \pm 1.8$ \\
\hline Age at T1 & $9.3 \pm 1.8$ \\
\hline Treatment Duration & $3.9 \pm 2.8$ \\
\hline \hline
\end{tabular}

Source: Authors.

Table 2 below shows the improvement in relation to the severity of OSAS, after treatment with RME. We can observe a reduction in severity in 6 cases, with improvement especially in the most severe cases of OSAS. 
Table 2 - Change in the severity of OSAS after RME treatment.

\begin{tabular}{c|c|c|c}
\hline \hline Severity & Light & Moderate & Severe \\
\hline \hline T0 & 7 & 12 & 7 \\
\hline T1 & 13 & 11 & 2 \\
\hline \hline
\end{tabular}

Source: Authors.

Statistical analysis was performed using the paired t-test of the variables BMI (Body Mass Index) and AHI (Apnea and Hypopnea Index), as shown in Table 3. We can see that there was a significant reduction in AIH after treatment with RME.

Table 3 - Variations in mean and standard deviation of body mass indices (BMI) and apnea and hypopnea index (AHI) before (T0) and after (T1) the RME treatment.

\begin{tabular}{c|c|c|c|c|c|c}
\cline { 2 - 6 } T0 & \multicolumn{3}{c|}{ T1 } \\
\hline \hline Measure & Mean & SD & Mean & SD & Test value & p value \\
\hline BMI & 19.79 & 4.33 & 20.13 & 4.53 & -0.73 & 0.48 \\
\hline AHI & 6.89 & 3.13 & 5.34 & 2.52 & 2.32 & 0.02 \\
\hline \hline
\end{tabular}

Source: Authors.

The variables of Obstructive Apnea Index (OAI), Central Apnea Index (CAI), Mixed Apnea (MA), Oxygen Desaturation Indices (ODI), Average Saturation (Mean Sat) and Severity were shown in Table 4, the last variable (Severity) being statistically significant ( $\mathrm{p}$ <.05), indicating that observing only one index does not show significant improvement, but the set of factors evaluated together led to a positive change in the severity of OSAS disease. For this purpose, the Wilcoxon test was performed.

Table 4 - OAI, CAI, MA, ODI and Mean Sat indices, with their respective means and interquartile range (IQR); p-value (significance) comparing before (T0) and after (T1) RME treatment.

\begin{tabular}{c|c|c|c|c|c|c}
\multicolumn{2}{c|}{ T0 } & \multicolumn{2}{c}{ T1 } \\
\hline \hline Measure & Mean & IQR & Mean & IQR & Test value & p value \\
\hline \hline OAI & 3.45 & 2.9 & 3 & 2.38 & 0.59 & 0.56 \\
\hline CAI & 0.5 & 1.28 & 0.35 & 0.98 & 1.03 & 0.31 \\
\hline MA & 0 & 0 & 0 & 0 & 0.53 & 0.59 \\
\hline ODI & 4.3 & 3.05 & 5.6 & 4.2 & 0.87 & 0.38 \\
\hline Mean Sat & 96 & 0.75 & 96 & 1.75 & 0.65 & 0.51 \\
\hline \hline Severity & 2 & 1.5 & 1.5 & 1 & 2.07 & 0.04 \\
\hline
\end{tabular}

Source: Authors.

Taking into account the questionnaires answered by the patients, we noticed that there was an important reduction in the averages of each questionnaire, the data being statistically significant (Table 5). 
Table 5 - Average of the total scores and standard deviation of the OSA-18 and Sleep Disorders Scale with their respective p values (significance) before (T0) and after (T1) the treatment of RME.

\begin{tabular}{c|c|c|c}
\hline \hline Questionnaire & T0 & T1 & p value \\
\hline \hline OSA-18 & $56.93 \pm 22.48$ & $25.81 \pm 9.22$ & 0.0001 \\
\hline Sleep disturbance scale in children & $66.3 \pm 26.69$ & $35.7 \pm 7.79$ & 0.0001 \\
\hline \hline
\end{tabular}

Source: Authors.

It was observed that the impact of OSAS on the quality of life of these patients, measured using the OSA-18 questionnaire, improved a lot after treatment, as shown in Table 6.

Table 6 - Index of impact on the quality of life of OSAS in 26 children before (T0) and after (T1) of treatment with RME.

\begin{tabular}{c|c|c|c|c}
\hline \hline \multirow{2}{*}{ OSA-18 Total Score } & \multicolumn{2}{c|}{ Frequency (n) } & \multicolumn{2}{c}{ Percentage (\%) } \\
\cline { 2 - 5 } & T0 & T1 & T0 & T1 \\
\hline \hline$<60$ (light) & 15 & 27 & 55.55 & 100 \\
\hline $\mathbf{6 0 - 8 0}$ (moderate) & 5 & 0 & 18.51 & 0 \\
\hline$>\mathbf{8 0}$ (severe) & 7 & 0 & 25.92 & 0 \\
\hline \hline
\end{tabular}

Source: Authors.

This study evaluated the repercussion of RME in children with obstructive respiratory disorders during the sleep with polysomnographic monitoring and quality of life and sleep. Due to the high prevalence of patients with OSAS, and the growing demand for research and treatment, the performance of conventional polysomnography has proved to be impractical, both for cost and for the availability of laboratories to perform it. Thus, portable monitoring devices (in this case, the Stardust II - STDII) are considered important tools for the diagnosis of OSAS, replacing the conventional exam, as it is more accepted in children, in addition to being more affordable (Campostrini DDA, 2014).

The device records data from the moment the patient is ready to sleep until the moment he wakes up the next morning. This autonomous method contributed to sleep more within the normal range of each patient's habits, which is an advantage that does not occur in polysomnography (PSG) under laboratory supervision. The way of use and the placement of the device were well explained to the guardian / companion, who contributed to the analysis to be performed correctly after the patient fell asleep. As the patients were minors, we suggest that monitoring be done by family members to avoid the excessive loss of data that could be caused by the detachment of the sensors.

The STD II device provides results from the apnea-hypopnea indexes that are in accordance with the diagnoses determined from conventional and supervised polysomnography. There was a lower-than-expected technical failure rate and successful use by patients in the home setting (Aurora et al., 2011). These data demonstrated that the Stardust II device is a reliable tool for diagnosing patients referred for OSAS assessment. This study corroborates with that of Certal et al. (2015), who indicated that the unattended multichannel devices have a good diagnostic performance to predict pediatric OSAS, as the results are useful, with moderate sensitivity and specificity.

Children from 7 to 11 years of age are the most effective age group to practice this type of interceptive study, since this period of transition from deciduous dentition to permanent denture is a period rich in biological events including dentition exchange, craniofacial growth and dimensional changes in dental arches, being the best time to perform orthodontic / orthopedic interceptive treatment (Moscatiello, Lederman, Moscatiello, Faltin Júnior, \& Moscatiello, 2008). 
The treatment of Sleep Respiratory Disorders in children through rapid maxillary expansion (RME) and mandibular advancement with intraoral devices has been recommended because they are conservative methods. ERM is a well-known orthodontic procedure, and scientific studies have proven its efficiency in the treatment of sleep-disordered breathing in children (Ruiz et al., 2018), which was also confirmed by our study, as 16 patients had an improvement in OSAS. Better results are still found when it is associated with adenotonsillar surgery, regardless of the order of the procedures (C. Guilleminault et al., 2011; Christian Guilleminault, Quo, Huynh, \& Li, 2008).

Several studies in the scientific literature have demonstrated the impact of obstructive sleep disorders on children's quality of life (Bergeron \& Ishman, 2021; Caixeta et al., 2021; Campbell, Mather, \& Elder, 2020). Behavioral problems such as hyperactivity, aggression, agitation, decreased concentration and school difficulties are more prevalent in these patients (Bandyopadhyay \& Slaven, 2021; Kaihua et al., 2019). When OSAS is diagnosed and treated early, these disorders improve (Lipton \& Gozal, 2003). However, when left untreated, especially in critical periods of brain development and growth, neurocognitive changes may not completely regress, and these children may experience a sustained decrease in learning (Gozal, 1998).

Gozal (1998) demonstrated that in children with school learning problems, the incidence of OSAS is 6 to 9 times higher than in the pediatric population in general. Urschitz et al. (2003) found a significant association between snoring and poor school performance even in the absence of intermittent hypoxia. Fortunately, research has shown that after treating Sleep Respiratory Disorders, children have improved learning and behavior (Ali, Pitson, \& Stradling, 1996; Gozal, 1998; Stradling, Thomas, Warley, Williams, \& Freeland, 1990). The results found in the present study also confirm that the treatment caused an improvement in both breathing (16 cases out of 26 analyzed had a reduction in the severity of Obstructive Sleep Apnea Syndrome) and in quality of life (13 patients stated that the impact on the quality of life went from moderate to severe to mild).

The population must have preventive and interceptive orthodontic treatments in the Primary Care Network (PC). But, although many dental surgeons are in favor and show interest, many consider themselves little or not able to perform it. Also, the lack of financial and human resources are factors that hinder the expansion of treatment in PC, given the high demand for basic and urgent procedures, making it impossible to operate in a completely satisfactory manner. The availability of an adequate physical structure, the definition of treatment protocols, in addition to professional training and adequate management of the service could be factors to contribute in this regard (Guzzo, Finkler, Reibnitz Júnior, \& Reibnitz, 2014).

In the state of São Paulo, a survey carried out in 1996 estimated the prevalence of occlusal problems, finding $48.97 \%$ at 5 years old and $71.31 \%$ at 12 years old. Considering moderate or severe anomalies, according to criteria recommended by the World Health Organization in 1987, the percentage was $26.12 \%$ in the primary dentition and $39.79 \%$ in the mixed dentition, respectively (Frazão, Narvai, Latorre, \& Castellanos, 2002). This research points to the large percentage of children with harmful habits and their predominant influence on craniofacial development and the installation of malocclusions, especially open and crossbites.

Some limitations of the study must be considered since the sample was from a small and previously selected group. However, the purpose of this study was to analyze the quality of life specifically related to a group of diseases - obstructive sleep disorders - after the treatment of rapid maxillary expansion and, for this purpose, the studied group largely met the needs.

\section{Conclusion}

There was a significant improvement in the patients' quality of life, as well as a reduction in the symptoms of sleepdisordered breathing, after the rapid maxillary expansion orthodontic-orthopedic treatment. Considering the promising results found in the present study, it would be interesting to follow-up these patients to ensure that the benefits of the treatment will be long-lasting. In addition, complementary studies to evaluate the airflow dimensions before and after rapid maxillary expansion 
as well as the association with other of appliances (i.e., mandibular advancement) as a way to further improve the effectiveness of breathing as well as the quality of life of patients should be considered in future studies.

\section{Acknowledgments}

This study was financed in part by the Coordenação de Aperfeiçoamento de Pessoal de Nível Superior - Brasil (CAPES) - Finance Code 001).

\section{References}

Ali, N. J., Pitson, D., \& Stradling, J. R. (1996). Sleep disordered breathing: effects of adenotonsillectomy on behaviour and psychological functioning. European Journal of Pediatrics, 155(1), 56-62. 10.1007/bf02115629

Aurora, R. N., Zak, R. S., Karippot, A., Lamm, C. I., Morgenthaler, T. I., ... Auerbach, S. H., (2011). American Academy of Sleep, Practice parameters for the respiratory indications for polysomnography in children. Sleep, 34(3), 379-388. 10.1093/sleep/34.3.379

Bandyopadhyay, A., \& Slaven, J. E. (2021). Health outcomes associated with improvement in mouth breathing in children with OSA. Sleep Breath. $10.1007 / \mathrm{s} 11325-020-02247-2$

Bergeron, M., \& Ishman, S. L. (2021). Persistent Obstructive Sleep Apnea Burden on Family Finances and Quality of Life. Otolaryngology and Head and Neck Surgery, 194599820986566. 10.1177/0194599820986566

Bruni, O., Ottaviano, S., Guidetti, V., Romoli, M., Innocenzi, M., Cortesi, F., \& Giannotti, F. (1996). The Sleep Disturbance Scale for Children (SDSC). Construction and validation of an instrument to evaluate sleep disturbances in childhood and adolescence. Journal of Sleep Research, 5(4), 251-261. 10.1111/j.1365-2869.1996.00251.x

Caixeta, J. A. S., Sampaio, J. C. S., Costa, V. V., Silveira, I., Oliveira, C. R. F., Caixeta, L., \& Avelino, M. A. G. (2021). Long-term Impact of Adenotonsillectomy on the Quality of Life of Children with Sleep-disordered breathing. Int Arch Otorhinolaryngol, 25(1), e123-e128. 10.1055/s-00401709195

Campbell, A. J., Mather, S. J., \& Elder, D. E. (2020). Obstructive sleep apnea risk factors and symptoms in children with a known parental obstructive sleep apnea diagnosis. Sleep Medicine, 78, 149-152. 10.1016/j.sleep.2020.12.030

Campostrini D. D. A, P. L., Prado G. F. (2014). Síndrome da apneia obstrutiva do sono e doenças cardiovasculares. Rev Neurocienc, 22(1), 102-112. http://dx.doi.org/10.4181/RNC.2014.22.930.11p

Certal, V., Camacho, M., Winck, J. C., Capasso, R., Azevedo, I., \& Costa-Pereira, A. (2015). Unattended sleep studies in pediatric OSA: A systematic review and meta-analysis. The Laryngoscope, 125(1), 255-262. https://doi.org/10.1002/lary.24662

Chaves Junior CM, G. M., Guimarães TM, Dal Fabbro C, Bittencourt L. (2017). Qual modalidade de aparelho intraoral devo usar no tratamento de adultos com apneia do sono? Rev Clín Ortod Dental Press, 16(2), 68-74. http://dx.doi.org/10.14436/1676-6849.16.2.068-074.art

Costa, J. G., Galindo, T. M., Mattos, C. T., \& Cury-Saramago, A. A. (2017). Retention period after treatment of posterior crossbite with maxillary expansion: a systematic review. Dental Press Journal of Orthodontics, 22(2), 35-44. 10.1590/2177-6709.22.2.035-044.oar

Di Francesco, R. C., Fortes, F. S. G., \& Komatsu, C. L. (2004). Melhora da qualidade de vida em crianças após adenoamigdalectomia. Revista Brasileira de Otorrinolaringologia, 70, 748-751.

Fernandes, F. M. V. S., \& Teles, R. d. C. V. V. (2013). Questionário da Síndrome da Apneia Obstrutiva na Criança-18: versão portuguesa. Brazilian Journal of Otorhinolaryngology, 79, 720-726. http://www.scielo.br/scielo.php?script=sci_arttext\&pid=S1808-86942013000600720\&nrm=iso

Fernandes, L. C., Farinazzo Vitral, R. W., Noritomi, P. Y., Schmitberger, C. A., \& José da Silva Campos, M. (2019). Influence of the hyrax expander screw position on stress distribution in the maxilla: A study with finite elements. American Journal of Orthodontics and Dentofacial Orthopedics, $155(1)$, 80-87. 10.1016/j.ajodo.2018.03.019

Ferreira, V. R., Carvalho, L. B., Ruotolo, F., de Morais, J. F., Prado, L. B., \& Prado, G. F. (2009). Sleep disturbance scale for children: translation, cultural adaptation, and validation. Sleep Medicine, 10(4), 457-463. 10.1016/j.sleep.2008.03.018

Franco, R. A., Jr., Rosenfeld, R. M., \& Rao, M. (2000). First place--resident clinical science award 1999. Quality of life for children with obstructive sleep apnea. Otolaryngology and Head and Neck Surgery, 123(1 Pt 1), 9-16. 10.1067/mhn.2000.105254

Frazão, P., Narvai, P. C., Latorre, M. d. R. D. d. O., \& Castellanos, R. A. (2002). Prevalência de oclusopatia na dentição decídua e permanente de crianças na cidade de São Paulo, Brasil, 1996. Cadernos de Saúde Publica, 18, 1197-1205. http://www.scielo.br/scielo.php?script=sci_arttext\&pid=S0102$311 \mathrm{X} 2002000500012 \&$ nrm=iso

Gozal, D. (1998). Sleep-disordered breathing and school performance in children. Pediatrics, 102(3 Pt 1), 616-620. 10.1542/peds.102.3.616

Guilleminault, C., Monteyrol, P. J., Huynh, N. T., Pirelli, P., Quo, S., \& Li, K. (2011). Adeno-tonsillectomy and rapid maxillary distraction in pre-pubertal children, a pilot study. Sleep Breath, 15(2), 173-177. 10.1007/s11325-010-0419-3

Guilleminault, C., Quo, S., Huynh, N. T., \& Li, K. (2008). Orthodontic expansion treatment and adenotonsillectomy in the treatment of obstructive sleep apnea in prepubertal children. Sleep, 31(7), 953-957. https://pubmed.ncbi.nlm.nih.gov/18652090 
https://www.ncbi.nlm.nih.gov/pmc/articles/PMC2491503/

Guzzo, S. C., Finkler, M., Reibnitz Júnior, C., \& Reibnitz, M. T. (2014). Ortodontia preventiva e interceptativa na rede de atenção básica do SUS: perspectiva dos cirurgiões-dentistas da Prefeitura Municipal de Florianópolis, Brasil. Ciência \& Saúde Coletiva, 19, 449-460. http://www.scielo.br/scielo.php?script=sci_arttext\&pid=S1413-81232014000200449\&nrm=iso

Huynh, N. T., Desplats, E., \& Almeida, F. R. (2016). Orthodontics treatments for managing obstructive sleep apnea syndrome in children: A systematic review and meta-analysis. Sleep Medicine Reviews, 25, 84-94. 10.1016/j.smrv.2015.02.002

Kaditis, A. G., Alonso Alvarez, M. L., Boudewyns, A., Alexopoulos, E. I., Ersu, R., Joosten, K., ... Verhulst, S. (2016). Obstructive sleep disordered breathing in 2- to 18-year-old children: diagnosis and management. European Respiratory Journal, 47(1), 69-94. 10.1183/13993003.00385-2015

Kaihua, J., Yang, Y., Fangqiao, Z., Huijuan, S., Chaoqun, W., \& Xuan, D. (2019). Event-related potentials and behavior performance scores in children with sleep-disordered breathing. Brain and Development, 41(8), 662-670. 10.1016/j.braindev.2019.04.008

Kapur, V. K., Auckley, D. H., Chowdhuri, S., Kuhlmann, D. C., Mehra, R., Ramar, K., \& Harrod, C. G. (2017). Clinical Practice Guideline for Diagnostic Testing for Adult Obstructive Sleep Apnea: An American Academy of Sleep Medicine Clinical Practice Guideline. Journal of Clinical Sleep Medicine, 13(3), 479-504. 10.5664/jcsm.6506

Lipton, A. J., \& Gozal, D. (2003). Treatment of obstructive sleep apnea in children: do we really know how? Sleep Medicine Reviews, 7(1), 61-80. $10.1053 /$ smrv.2001.0256

Luzzi, V., Di Carlo, G., Saccucci, M., Ierardo, G., Guglielmo, E., Fabbrizi, M., ... Polimeni, A. (2016). Craniofacial morphology and airflow in children with primary snoring. European Review for Medical and Pharmacological Sciences, 20(19), 3965-3971. https://www.ncbi.nlm.nih.gov/pubmed/27775805

Maspero, C., Cavagnetto, D., Fama, A., Giannini, L., Galbiati, G., \& Farronato, M. (2020). Hyrax versus transverse sagittal maxillary expander: An assessment of arch changes on dental casts. A retrospective study. Saudi Dent J, 32(2), 93-100. 10.1016/j.sdentj.2019.06.003

Moscatiello, V. A. M., Lederman, H., Moscatiello, R. A., Faltin Júnior, K., \& Moscatiello, R. M. (2008). Maturação das vértebras cervicais e sua correlação com a idade óssea da mão e punho como indicadores no tratamento ortodôntico. Revista Dental Press de Ortodontia e Ortopedia Facial, 13, 92-100. http://www.scielo.br/scielo.php?script=sci_arttext\&pid=S1415-54192008000400011\&nrm=iso

Pereira, A. S., Sitsuka, D. M., Pereira, F.J., \& Shitsuka, R. (2018). Metodologia da Pesquisa Científica. Santa Maria, RS: UAB/NTE/UFSM.

Pirelli, P., Saponara, M., \& Guilleminault, C. (2004). Rapid maxillary expansion in children with obstructive sleep apnea syndrome. Sleep, 27(4), 761-766. 10.1093/sleep/27.4.761

Rana, M., August, J., Levi, J., Parsi, G., Motro, M., \& DeBassio, W. (2020). Alternative Approaches to Adenotonsillectomy and Continuous Positive Airway Pressure (CPAP) for the Management of Pediatric Obstructive Sleep Apnea (OSA): A Review. Sleep Disord, 2020, 7987208. 10.1155/2020/7987208

Ruiz, V. F., Cruz, C. M. d., Ferreira, D., Aguiar, A. P. d., \& Silva, L. M. d. (2018). EXPANSÃO RÁPIDA DA MAXILA. REVISTA FAIPE(2), 105-109\%V 107. https://revistafaipe.com.br/index.php/RFAIPE/article/view/89

Stradling, J. R., Thomas, G., Warley, A. R., Williams, P., \& Freeland, A. (1990). Effect of adenotonsillectomy on nocturnal hypoxaemia, sleep disturbance, and symptoms in snoring children. Lancet, 335(8684), 249-253. 10.1016/0140-6736(90)90068-g

Tan, H. L., Alonso Alvarez, M. L., Tsaoussoglou, M., Weber, S., \& Kaditis, A. G. (2017). When and why to treat the child who snores? Pediatric Pulmonology, 52(3), 399-412. 10.1002/ppul.23658

Urschitz, M. S., Guenther, A., Eggebrecht, E., Wolff, J., Urschitz-Duprat, P. M., Schlaud, M., \& Poets, C. F. (2003). Snoring, intermittent hypoxia and academic performance in primary school children. American Journal of Respiratory and Critical Care Medicine, 168(4), 464-468. 10.1164/rccm.20021213970C

Weissheimer, A., de Menezes, L. M., Mezomo, M., Dias, D. M., de Lima, E. M., \& Rizzatto, S. M. (2011). Immediate effects of rapid maxillary expansion with Haas-type and hyrax-type expanders: a randomized clinical trial. American Journal of Orthodontics and Dentofacial Orthopedics, 140(3), 366-376. 10.1016/j.ajodo.2010.07.025 